\title{
Formulações de Anestésicos Locais de Liberação Controlada: Aplicações Terapêuticas *
}

\section{Drug-Delivery Systems for Local Anesthetics: Therapeutic Applications}

\author{
Daniele Ribeiro de Araújo ${ }^{1}$; Luciana de Matos Alves Pinto ${ }^{2}$; Angélica de Fátima de Assunção Braga, TSA $^{3}$;
} Eneida de Paula ${ }^{4}$

\author{
RESUMO \\ Araújo DR, Pinto LMA, Braga AFA, Paula E - Formulações de \\ Anestésicos Locais de Liberação Controlada: Aplicações Tera- \\ pêuticas
}

JUSTIFICATIVA E OBJETIVOS: O desenvolvimento de sistemas de liberação controlada tem sido alvo de pesquisas há pelo menos quatro décadas. Desde que foi sugerida sua aplicação na indústria farmacêutica, muitos resultados foram obtidos, especialmente na manipulação molecular de carreadores e no estudo de suas interações com as drogas encapsuladas. Esses novos carreadores têm a vantagem de contornar propriedades físico-químicas limitantes (como a solubilidade aquosa ou em membranas) das drogas encapsuladas, melhorando assim a farmacodinâmica (potencialização do efeito terapêutico), farmacocinética (controle da absorção e distribuição tecidual) e os efeitos toxicológicos (redução da toxicidade local e sistêmica) das mesmas. Entre os principais carreadores, destacam-se os lipossomas e as ciclodextrinas, que vêm trazendo inúmeras vantagens no desenvolvimento de formulações para liberação controlada de anestésicos locais. Este trabalho de revisão objetiva descrever a interação de anestésicos locais com lipossomas ou ciclodextrinas, o desenvolvimento das pesquisas básica e clínica nessa área, além da aplicabilidade terapêutica dessas formulações.

CONTEÚDO: Lipossomas têm a capacidade de veicular drogas em órgãos-alvo, disponibilizando apenas uma fração liberação controlada - para o sítio de ação. Já as ciclodextrinas alteram a intensidade e a duração do efeitos das drogas através da baixa absorção sistêmica do complexo. Pesquisas básicas e clínicas apontam como vantagens do uso de anestésicos locais encapsulados em lipossomas ou complexados com ciclodextrinas a liberação lenta da droga que prolonga a duração da anestesia e reduz a toxicidade para os sistemas cardiovascular e nervoso central.

* Recebido do (Received from) Departamento de Bioquímica, Instituto de Biologia da Universidade Estadual de Campinas, UNICAMP

1. Doutoranda em Biologia Funcional e Molecular - Bioquímica, Universidade Estadual de Campinas - UNICAMP

2. Doutora em Biologia Funcional e Molecular - Bioquímica, Universidade Estadual de Campinas - UNICAMP

3. Professora Doutora do Departamento de Anestesiologia da Faculdade de Ciências Médicas da Universidade de Campinas - UNICAMP

4. Professora Associada (MS5) do Departamento de Bioquímica, Instituto de Biologia da Universidade Estadual de Campinas, UNICAMP

Apresentado (Submitted) em 04 de outubro de 2002

Aceito (Accepted) publicação em 31 de janeiro de 2003

Endereço para Correspondência (Correspondence to)

Dra. Daniele Ribeiro de Araújo

Dept ${ }^{\circ}$ de Bioquímica - Instituto de Biologia - UNICAMP

Caixa Postal, 6109

13083-970 Campinas, $S P$

E-mail:daraujo@unicamp.br

(c) Sociedade Brasileira de Anestesiologia, 2003
CONCLUSÕES: Embora várias pesquisas ainda estejam em andamento, os sistemas de liberação controlada de anestésicos locais indicam uma nova direção no desenvolvimento de formulações anestésicas mais eficazes e seguras.

Unitermos: ANESTÉSICOS: Local

\section{SUMMARY}

Araújo DR, Pinto LMA, Braga AFA, Paula E - Drug-Delivery Systems for Local Anesthetics: Therapeutic Applications

BACKGROUND AND OBJECTIVES: Many researchers in the last four decades have been devoted to the development of drug-delivery systems. Since its first application in the pharmaceutical industry, many results have been obtained especially in the molecular manipulation of carriers and their interaction with encapsulated drugs. These new carriers have the advantage of bypassing encapsulated drugs restraining physicochemical properties (such as water or membrane solubility), thus improving pharmacodynamics (therapeutic effect potentiation), pharmacokinetics (control of tissue absorption and distribution) and toxic effects (lower local and systemic toxicity). Liposomes and cyclodextrins are among the most important carriers which have shown to be quite advantageous in the development of drug-delivery systems for local anesthetics. This study aimed at reviewing the interaction of local anesthetics with liposomes and cyclodextrins, the development of basic and applied research on the field, in addition to therapeutic applicability of these formulations.

CONTENTS: Liposomes have the ability to control drug delivery to target tissues, fractionating drug release in its site of action. Cyclodextrins, on the other hand, change intensity and duration of effects due to low systemic drug absorption. Basic and clinical studies have pointed out that the administration of local anesthetics in liposome or cyclodextrin formulations induces slow release of the drugs, prolonging the anesthetic action and decreasing cardiac and nervous systems toxicity.

CONCLUSIONS: Although studies are still in progress, drug-delivery systems are flagging a new direction for the development of safer and more effective local anesthetic formulations.

Key Words: ANESTHETICS: Local

\section{INTRODUÇÃO}

Lá muito existe a preocupação em compreender o fenô1 meno da dor e, conseqüentemente, conceituá-lo. Segundo a Associação Internacional para o Estudo da Dor, esse fenômeno é caracterizado por uma experiência sensitiva e emocional desagradável, em que há percepção de um estímulo nocivo associado à lesão tecidual real ou potencial. De acordo com a duração da lesão tecidual pode-se classificar a dor em aguda ou de curta duração, que persiste ape- 
nas enquanto durar o dano representando uma reação fisiológica normal; e a dor crônica ou lenta, associada às lesões mais profundas, evidenciando-se quando cessa a função dos mecanismos normais de cicatrização e estados patológicos que podem persistir por um longo período, como câncer, artrite reumatóide e pinçamentos nervosos ${ }^{1}$. Apesar de incômoda, a dor desempenha uma função biológica essencial. É a resposta do organismo a um determinado ou potencial trauma. Porém, em algumas situações, o sofrimento doloroso perde sua função biológica e começa a representar uma conseqüência insuportável às desordens refratárias ao tratamento. Por isso, a capacidade de instituir novos métodos de tratamento com o objetivo de produzir analgesia, isto é, aliviar ou eliminar a dor, é um desafio atual. Os avanços nas pesquisas básica e clínica têm expandido as opções na farmacoterapia da dor. Para pacientes com câncer ou dor neuropática, por exemplo, a farmacoterapia é a principal ou senão a única saída para mantê-la sob controle. Muitos fármacos têm sido utilizados (anticonvulsivantes, agonistas GABAérgicos, neurolépticos), inclusive, a combinação de anestésicos locais e analgésicos opióides (bupivacaína - morfina) tem sido sugerida tanto para tratamento da dor pós-operatória quanto para a dor neuropática em pacientes que não respondem ao tratamento somente com opióides, pois a liberação subaracnóidea da combinação resulta em um ritmo mais lento no aparecimento da tolerância aos opióides. Porém, pesquisas ainda são necessárias para a determinação dos limites de toxicidade dessa associação ${ }^{2,3}$. A dor também pode ser controlada pelo uso de anestésicos locais para o bloqueio de nervos periféricos específicos, embora esses fármacos apresentem limitações devido a sua duração de ação relativamente curta (2 a 4 horas). Nas últimas décadas, alguns anestésicos locais como lidocaína, bupivacaína e, mais recentemente, levobupivacaína e ropivacaína, têm sido introduzidos na terapia da dor aguda e crônica na tentativa de melhorar a ação dos fármacos já utilizados ${ }^{4}$. As características desejáveis para uma molécula anestésica são: a longa duração de ação, diminuição da toxicidade local e/ou sistêmica e aumento da seletividade para o bloqueio sensorial, em relação ao bloqueio motor ${ }^{5}$. Com a alteração de propriedades físicas e químicas na molécula dos anestésicos locais (síntese direcionada por estudos de correlação estrutura-função), alguns desses objetivos têm sido atingidos. Mas uma alternativa, que atualmente vem promovendo os efeitos desejáveis, éa liberação controlada desses fármacos através da encapsulação em lipossomas e/ou outros veículos, como complexos com ciclodextrinas ${ }^{6}$.

\section{LIPOSSOMAS}

Os lipossomas, descobertos em 1963, consistem de esferas microscópicas de tamanhos variados (em escalas de nm e $\mu \mathrm{m}$ ) com uma ou mais bicamadas lipídicas concêntricas separadas por compartimentos aquosos, onde as caudas hidrofóbicas dos lipídios estão voltadas para o interior e as cabeças polares para o exterior da bicamada (Figura 1), mantendo contato com a fase aquosa ${ }^{7}$.
A natureza da interação entre os lipídios, a composição dos mesmos e o método de preparação determinam o padrão, o tamanho e o número de bicamadas formadas, sendo os lipossomas (quanto ao número de bicamadas) classificados em vesículas multi (MLV) ou unilamelares (LUV) (Figuras 1 e 2), influenciando diretamente na absorção, distribuição, metabolismo, eliminação e no perfil de toxicidade das drogas encapsuladas $^{8}$. O tamanho do lipossoma afeta a biodistribuição, pois, após administração subcutânea, lipossomas menores que $120 \mathrm{~nm}$ atravessam rapidamente os capilares, enquanto que lipossomas maiores (com cerca de $200 \mathrm{~nm}$ ou mais) tendem a permanecer no local de injeção ${ }^{9}$.

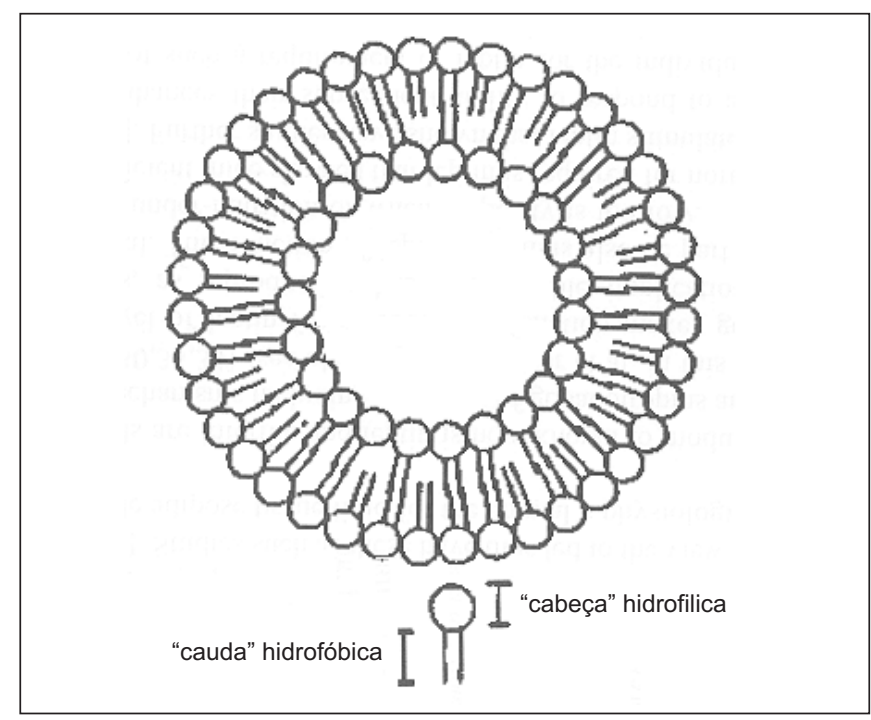

Figura 1 - Representação Esquemática da Organização de um Lipossoma Unilamelar (LUV), Ressaltando a Disposição das Porções Hidrofílica e Hidrofóbica dos Fosfolipídios

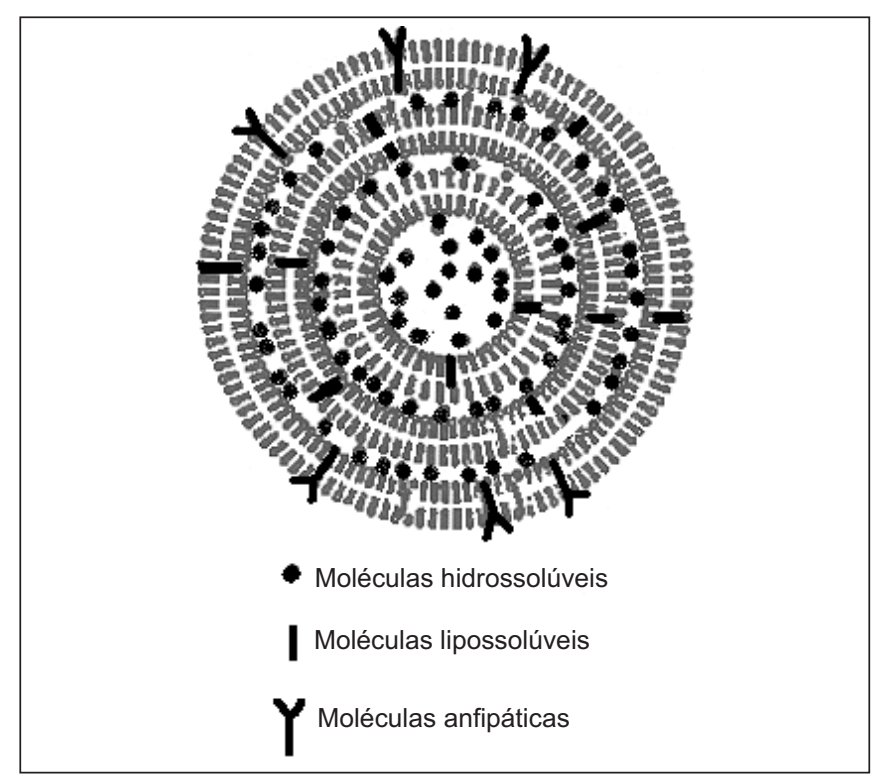

Figura 2 - Direcionamento da Encapsulação de Drogas em um Lipossoma Multilamelar (MLV): Moléculas Hidrossolúveis, Lipossolúveis e Anfipáticas

Revista Brasileira de Anestesiologia Vol. 53, N ${ }^{\circ} 5$, Setembro - Outubro, 2003 
Já a encapsulação de drogas é orientada pela hidro ou lipofilicidade das mesmas. Drogas hidrofílicas têm tendência a permanecer no compartimento central aquoso e drogas hidrofóbicas encontram-se dispersas na bicamada lipídica (Figura 2). Além disso, drogas lipofílicas permanecem mais tempo encapsuladas devido ao alto particionamento na fase membranar ${ }^{10}$.

A função dos lipossomas como veículos é liberar determinadas concentrações de drogas em alvos específicos, evitando a toxicidade sistêmica, já que somente uma fração da droga está disponível para o local de ação ${ }^{9}$.

A similaridade dos monômeros lipídicos constituintes dos lipossomas (fosfatidilcolina derivada de ovo, soja ou sintéticas e colesterol, em geral) com as membranas biológicas elimina o risco de antigenicidade ou lesões histológicas após a administração desses veículos ${ }^{11}$.

Lipossomas têm sido utilizados em imunoensaios ${ }^{12}$ e como sistemas de liberação controlada para várias drogas incluindo antivirais ${ }^{13}$, antifúngicos ${ }^{14}$, no desenvolvimento de vacinas ${ }^{15}$ e de medicamentos anti-câncer ${ }^{16}$ e também para meIhorar as propriedades terapêuticas de anestésicos locais. Trabalhos realizados em animais de laboratório e em humanos, utilizando bupivacaína em lipossomas multilamelares, apresentaram resultados satisfatórios no tratamento da dor crônica e pós-operatória com relação ao aumento na duração da anestesia, do bloqueio nervoso diferencial (potencialização da analgesia sem bloqueio motor), além de permitir o controle dos níveis sistêmicos da droga ${ }^{11,17-23}$

Uma interessante revisão sobre o uso de anestésicos locais e opióides encapsulados em lipossomas foi feita por Simonetti e col. ${ }^{24}$ e publicada nesta revista. De maneira geral, pode-se dizer que o uso de anestésicos locais encapsulados em lipossomas tem como vantagens a liberação lenta da droga, prolongando a duração da anestesia e a redução da toxicidade para os sistemas cardiovascular e nervoso central $^{25,26}$

\section{CICLODEXTRINAS}

A hidrólise enzimática do amido usualmente resulta na formação de glicose, maltose e em uma longa classe de dextrinas lineares e ramificadas. No entanto, alguns microorganismos e plantas (que produzem enzimas denominadas ciclodextrina glicosiltransferases) são capazes de degradar o amido em produtos cíclicos chamados ciclodextrinas ${ }^{27,28}$. As três ciclodextrinas naturais são a alfa ( $\alpha$-ciclodextrina), beta ( $\beta$-ciclodextrina) (Figura 3 ) e gama $(\gamma$-ciclodextrina) compostas de seis, sete e oito unidades de D-(+)-glicopiranose, respectivamente. Esses agentes têm em sua estrutura grupos hidroxil primários e secundários orientados para o exterior. Portanto, possuem um exterior hidrofílico e uma cavidade interna relativamente hidrofóbica que, por sua vez, permite as ciclodextrinas complexarem-se com moléculas que apresentam dimensões compatíveis com a sua cavidade. A complexação altera propriedades físico-químicas, como a solubilidade em água, estabilidade e biodisponibilidade de drogas complexadas ${ }^{29}$.

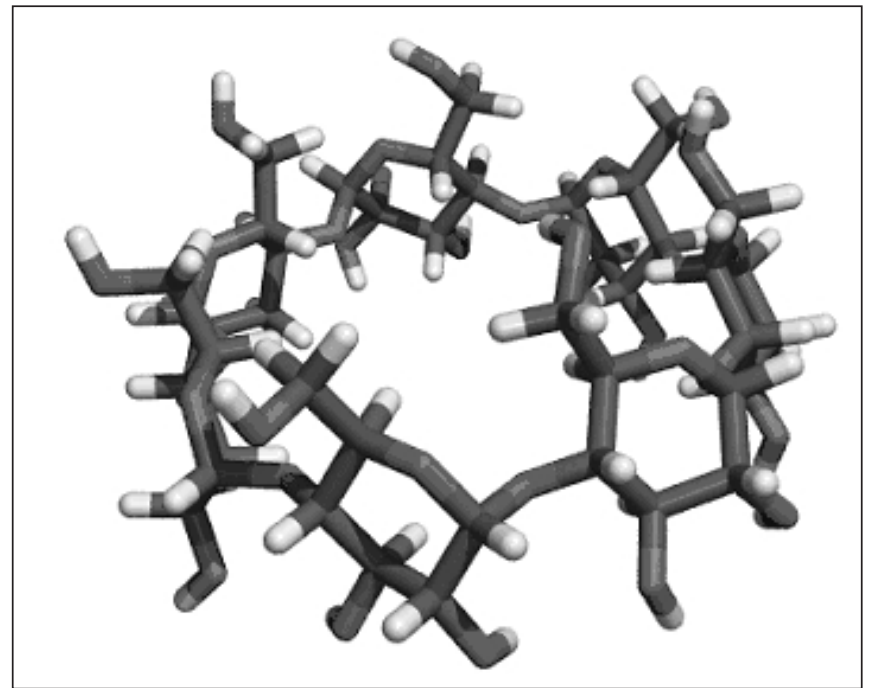

Figura 3 - Estrutura da $\beta$-Ciclodextrina com seus Sete Monômeros de Glicose

A habilidade das ciclodextrinas de formarem complexos de inclusão depende essencialmente da compatibilidade estérica e da polaridade com a droga. Além disso, as forças que dirigem a complexação têm sido atribuídas à alta energia de repulsão da água na cavidade das ciclodextrinas, às interações de van der Waals, pontes de hidrogênio e interações hidrofóbicas ${ }^{30}$, já que a cavidade interna tem diâmetros de 5 a $8 \AA^{28}$, sendo grande o bastante para acomodar um hexanel aromático, no caso da $\beta$-ciclodextrina ${ }^{31}$.

As moléculas complexadas permanecem, normalmente, orientadas em posição onde há o máximo contato entre sua porção hidrofóbica e a cavidade apolar (Figura 4), estando sua porção hidrofílica em contato com os grupos hidroxil da ciclodextrina ${ }^{32}$.

As $\beta$-ciclodextrinas são as dextrinas cíclicas mais largamente utilizadas para a complexação com várias classes de drogas, como: agentes antitumorais (doxorubicina) ${ }^{33}$, antidiabéticos (tolbutamida) ${ }^{34}$ e antiinflamatórios (piroxicam) ${ }^{35}$, que podem ser administrados por diversas vias como subaracnóidea, venosa, muscular, peridural, oral, nasal e dérmica $^{27,33-36}$.

As ciclodextrinas naturais, em particular a $\beta$-ciclodextrina, têm solubilidade aquosa limitada ( $16,4 \mathrm{mM}$ ou $18,6 \mathrm{mg} / \mathrm{ml}) \mathrm{e}$ a formação de complexos com compostos lipofílicos geralmente resulta em precipitação dos complexos sólidos, se o limite de solubilidade for atingido. Assim, numerosas modificações na estrutura química das $\beta$-ciclodextrinas têm sido feitas, originando derivados mais solúveis como 2,6-dimetil- $\beta$-ciclodextrina (DM- $\beta$-ciclodextrina), 2-hidroxipropil- $\beta$-ciclodextrina (HP- $\beta$-ciclodextrina) e ciclodextrinas sulfatadas como sulfobutiléter- $\beta$-ciclodextrina (SBE- $\beta$-ciclodextrina) ${ }^{37}$.

Além da estabilização, a modificação da farmacocinética e das propriedades biofarmacêuticas das drogas são os efeitos mais significantes da complexação com ciclodextrinas. 


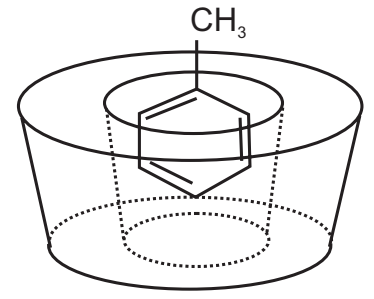

A

$(1: 1)$

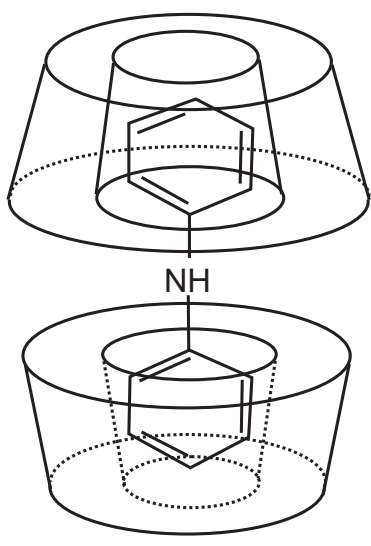

$(1: 2)$

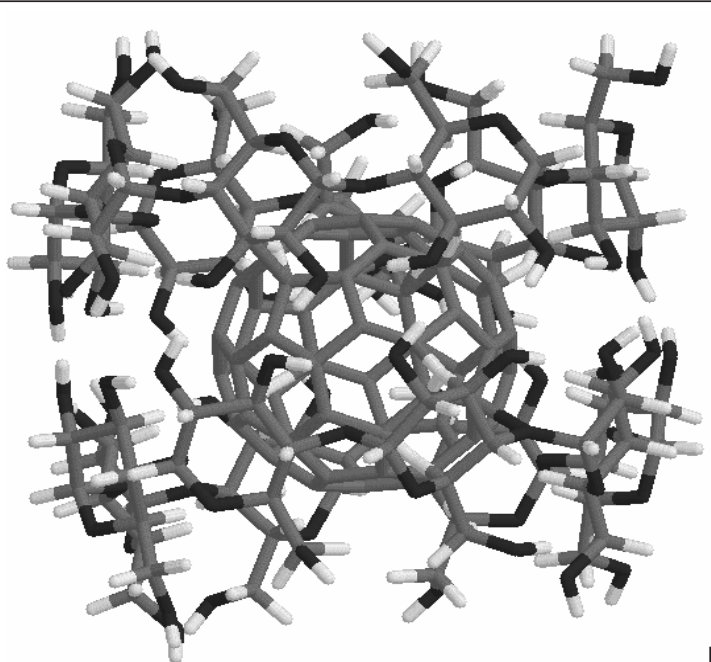

$B$

Figura 4 - Formação de Complexos de Inclusão entre Drogas e Ciclodextrina, nas Proporções de 1:1 e 1:2 (A) e Representação da Complexação $1: 2(B)$

Esses efeitos são observados especialmente na solubilidade e na liberação da droga complexada. Como conseqüência disso, a administração de fármacos complexados com $\beta$-ciclodextrina altera a intensidade e a duração de seus efeitos através da baixa absorção sistêmica das drogas ${ }^{32}$.

Essa propriedade das ciclodextrinas torna bastante promissor seu uso para a complexação com anestésicos locais. Além disso, estudos indicam que a utilização de $\beta$-ciclodextrina e alguns de seus derivados (dimetil e hidroxipropil $\beta$-ciclodextrina) aumentam a solubilidade de anestésicos locais como etidocaína, lidocaína, prilocaína, mepivacaína e, especialmente, bupivacaína - bem como melhoram os índices terapêuticos das drogas complexadas ${ }^{38-42}$.

\section{CONCLUSÕES}

O benefício terapêutico das várias drogas administradas na forma tradicionalé, algumas vezes, limitado pelas propriedades físico-químicas (solubilidade) e toxicológicas das mesmas ou até por barreiras fisiológicas. Através do desenvolvimento de sistemas de liberação controlada é possível manipular algumas dessas propriedades além de melhorar os efeitos terapêuticos das drogas, favorecendo sua utilização clínica. As pesquisas com formulações de anestésicos locais de liberação controlada têm mostrado resultados promissores.

Estudos em pacientes demonstraram a aplicabilidade e eficácia da encapsulação de bupivacaína $(0,5 \%)$ em lipossomas por administração peridural e infiltração no plexo braquial, no tratamento da dor pós-cirúrgica e dor crônica oncológica. Foi observada uma maior duração da analgesia, quando comparada àquela obtida após administração do anestésico local livre, além da potencialização do bloqueio nervoso diferencial. Esses resultados podem ser atribuídos à manutenção de altos níveis da droga no local de injeção
${ }^{22,23}$. Apesar dos grandes avanços no desenvolvimento dessas formulações, estudos ainda são necessários para a determinação da razão de liberação dos anestésicos em lipossomas e estabilidade das preparações, bem como para o controle de alguns efeitos como indução de bloqueio simpático. Por isso, modificações nos métodos de preparação e/ou variações na composição dos lipossomas têm sido utilizadas com o objetivo de aumentar a eficiência e a encapsulação de anestésicos locais ${ }^{43-46}$.

Com relação à complexação de anestésicos locais com ciclodextrinas, a utilização de derivados (menos tóxicos e mais solúveis) das $\beta$-ciclodextrinas com bupivacaína têm demonstrado um aumento no efeito anestésico aliado ao controle da absorção sistêmica da droga após administração epidural e infiltração intramuscular em animais de laboratório, promovendo a formulação como um sistema de liberação controlada potencialmente eficaz na farmacoterapia da dor ${ }^{40-42}$. Porém, essas formulações ainda necessitam ser submetidas a ensaios para avaliação da neurotoxicidade local de forma a garantir sua utilização segura em clínica.

Embora as pesquisas ainda estejam em andamento, é importante ressaltar que anestésicos locais encapsulados em lipossomas ou complexados com ciclodextrinas apontam uma nova direção no desenvolvimento de formulações mais eficazes e seguras. Pacientes submetidos a cirurgias (no alívio da dor pós-operatória) ou com dor crônica (que freqüentemente necessitam de administrações repetidas de anestésicos locais, seja para bloqueio de nervos periféricos, centrais ou autonômicos) seriam os principais beneficiados pelo desenvolvimento dessas formulações, denominadas de longa duração ou de liberação controlada, possibilitando aumento na duração da anestesia, diminuindo a freqüência de administrações diárias e reduzindo a toxicidade sistêmica inerente aos anestésicos locais atualmente disponíveis. 


\section{Drug-Delivery Systems for Local Anesthetics: Therapeutic Applications}

Daniele Ribeiro de Araújo, M.D.; Luciana de Matos Alves Pinto, M.D.; Angélica de Fátima de Assunção Braga, TSA, M.D.; Eneida de Paula, M.D.

\section{INTRODUCTION}

Understanding and, as a consequence, defining pain has been a long term concern. According to the International Association for the Study of Pain, this event is characterized by an uncomfortable sensory and emotional experience where there is the perception of a noxious stimulation associated to real or potential tissue injury. According to tissue injury duration, pain may be classified as acute, or short-duration pain, which persists while the damage persists and represents a normal physiological reaction; and chronic or slow pain, associated to deeper injuries and being present when normal healing systems mechanisms are no longer functioning, and to pathological states which may persist for a long time, such as cancer, rheumatoid arthritis and nerve clamping ${ }^{1}$.

Although uncomfortable, pain has an essential biological function. It is the body's response to a real or potential trauma. In some situations, however, pain loses its biological function and starts to represent an unbearable consequence of disorders refractory to treatment. So, the ability to develop new treatment methods aiming at producing analgesia, that is, relieve or eliminate pain, is our current challenge.

Basic and clinical research advances have expanded pain pharmacotherapy options. For cancer or neuropathic pain patients, for example, pharmacotherapy is the major, if not the only way to keep it under control. Several drugs have been used (anticonvulsants, GABAergic agonists, neuroleptics), and the combination of local anesthetics and opioids (bupivacaine - morphine) has been suggested both to treat postoperative pain and neuropathic pain in patients not responding to opioids alone, because spinal release of the combination results in a slower pace for the appearance of opioid tolerance. However, studies are still needed to establish toxicity thresholds of such association ${ }^{2,3}$.

Pain may also be controlled by local anesthetics blocking specific peripheral nerves; these drugs, however, are limited due to their relative short action ( 2 to 4 hours). In the last decade, some local anesthetics such as lidocaine, bupivacaine and, more recently, levobupivacaine and ropivacaine, have been introduced for acute and chronic pain therapy, in an attempt to improve the action of already used drugs ${ }^{4}$.

Desirable profile of an anesthetic molecule is: long duration, lower local and/or systemic toxicity and higher selectivity for sensory block as compared to motor block ${ }^{5}$. By changing physical and chemical properties of the local anesthetics molecule (synthesis oriented by quantitative structure-activity relationship), some of these objectives have been met. But an alternative, which is currently providing desirable effects, is the controlled delivery of these drugs through their encapsu- lation in liposomes and/or other vehicles, such as cyclodextrin complexes ${ }^{6}$.

\section{LIPOSOMES}

Developed in 1963, liposomes are microscopic spheres of different sizes (in $\mathrm{nm}$ and $\mu \mathrm{m}$ scales) with one or more concentric lipid bylayers separated by water compartments, where lipids hydrophobic tails are directed inwards and polar heads are directed outwards of the bylayer (Figure 1), keeping in touch with the water phase ${ }^{7}$.

Lipids interaction nature, their composition and preparation methods determine the pattern, size and number of bylayers, being liposomes classified (as to the number of bilayers) in multilamellar (MLV) or unilamellar (LUV) vesicles (Figures 1 and 2), directly influencing absorption, distribution, metabolism, excretion and toxicity profile of encapsulated drugs ${ }^{8}$. Liposome size affects biodistribution because after subcutaneous administration, liposomes smaller than $120 \mathrm{~nm}$ rapidly cross capillaries, while larger liposomes (approximately 200 $\mathrm{nm}$ or more) tend to remain in the injection site ${ }^{9}$.

Drugs encapsulation is oriented by their hydro or lipophilicity. Hydrophilic drugs tend to remain in the central water compartment and hydrophobic drugs are spread throughout the lipid bilayer (Figura 2). In addition, lipophilic drugs remain encapsulated for a long period due to high partitioning in the membrane phase ${ }^{10}$. The function of vehicle liposomes the controlled release drugs to specific targets avoiding systemic toxicity, since only a fraction of the drugs is available to the action site ${ }^{9}$. The similarity between lipid monomers making up liposomes (in general, egg, soybean-derived or synthetic phosphatidylcholine and cholesterol) and biological membranes constituents eliminates the risk for antigenicity or histological injuries after the administration of such vehycles ${ }^{11}$.

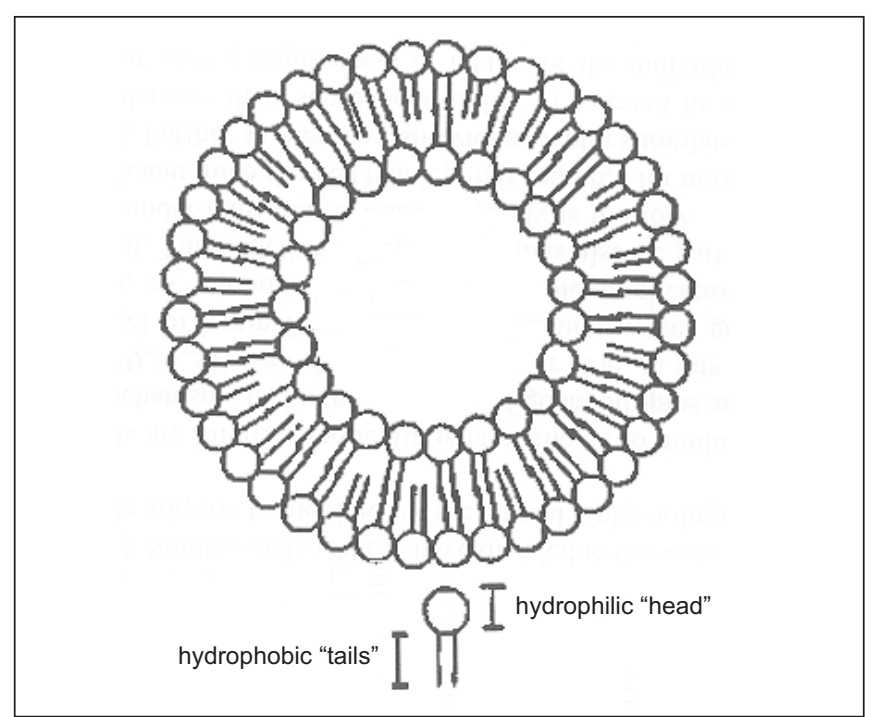

Figure 1 - Schematic of Unilamellar Liposome Organization, Highlighting Phospholipids Hydrophilic and Hydrophobic Portions Disposition 


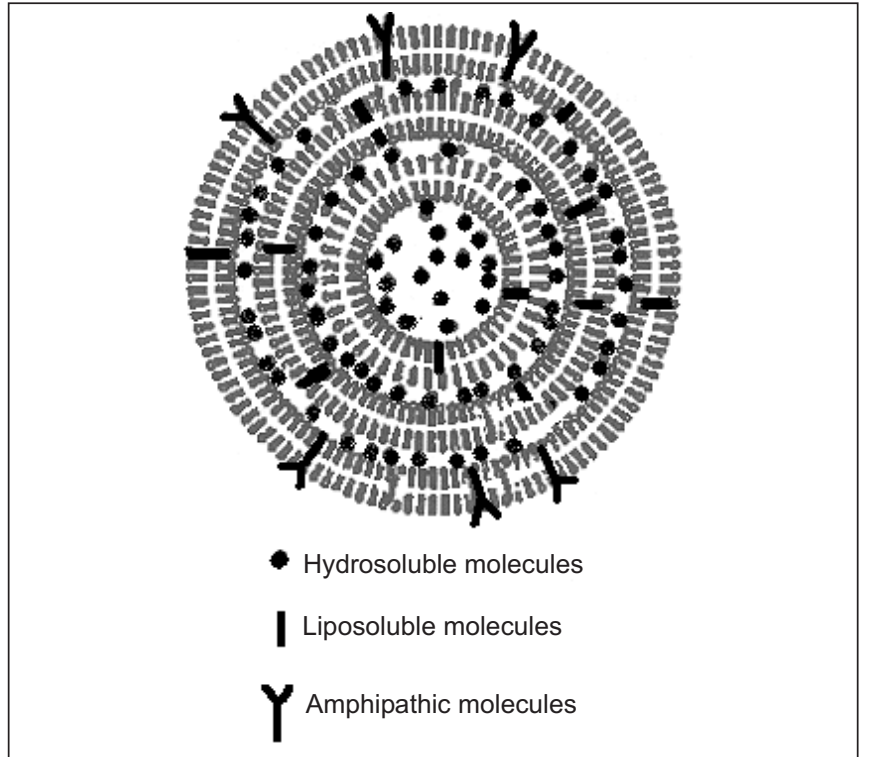

Figure 2 - Model of Drugs Encapsulation in Multilamellar Liposome: Hydrosoluble, Liposoluble and Amphipathic Molecules

Liposomes have been used in immune-essays ${ }^{12}$ and as drug-delivery systems for several drugs, including antiviral ${ }^{13}$ and antifungal ${ }^{14}$ drugs, in the development of vaccines ${ }^{15}$ and anti-cancer drugs ${ }^{16}$, and also to improve local anesthetic therapeutic properties.

Animal and human studies using bupivacaine in multilamellar liposomes, have shown satisfactory results in treating chronic and postoperative pain in terms of longer anesthetic and differential nervous block duration (potentiation of analgesia without motor block), in addition to allowing systemic drug levels control ${ }^{11,17-23}$.

An interesting review on the use of local anesthetics and liposome-encapsulated opioids was published by Simonetti et al. ${ }^{24}$ in the Brazilian Journal of Anesthesiology. In general, one may say that the use of liposome-encapsulated local anesthetics have the advantage of slow drug release prolonging anesthetic duration, and low cardiovascular and central nervous system toxicity ${ }^{25,26}$.

\section{CYCLODEXTRINS}

Enzymatic amide hydrolysis in general results in glucose, maltose and a large class of linear and branched dextrins. However, some microorganisms and plants (producing enzymes called glycosyltransferase cyclodextrins) are able to degrade amide in cyclic products called cyclodextrins ${ }^{27,28}$. The three natural cyclodextrins are alpha ( $\alpha$-cyclodextrin), beta ( $\beta$-cyclodextrin) (Figure 3 ) and gamma ( $\gamma$-cyclodextrin), composed of six, seven and eight D-(+)-glucopyranose units, respectively. These agents have primary and secondary hydroxyl groups oriented outwards. So, they are externally hydrophilic with a relatively hydrophobic interior, which allows cyclodextrins to complex with molecules compatible

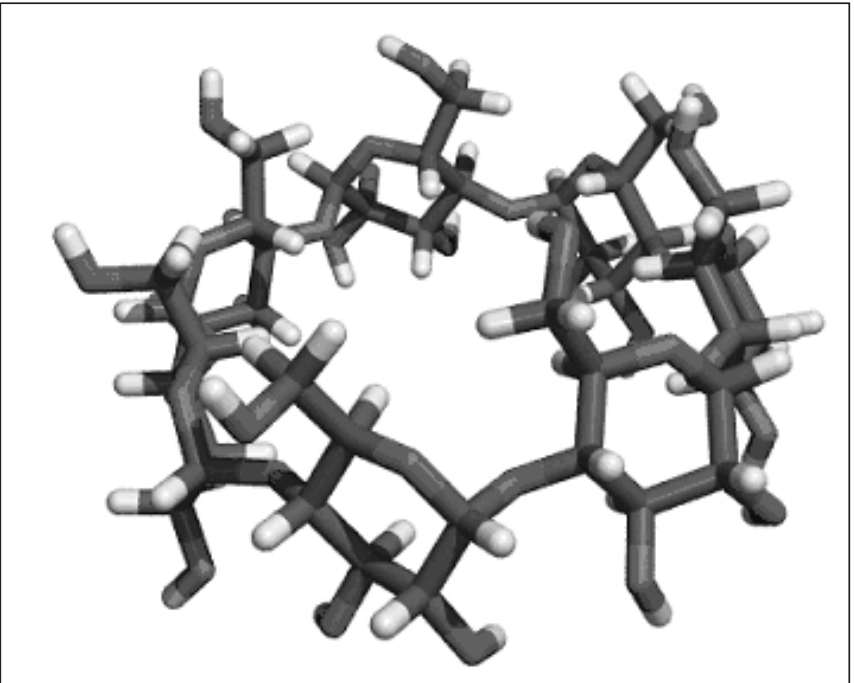

Figure 3 - $\beta$-Cyclodextrin Structures with its Seven Glucose Monomers

with their cavity size. Complexation changes physico-chemical properties, such as water solubility, stability and bioavailability of complexed drugs ${ }^{29}$.

Cyclodextrins ability to form inclusion complexes depends essentially on esteric and polarity compatibility with the drug. In addition, forces directing complexation have been attributed to high water repulsion energy in cyclodextrins cavity, to van der Waals interactions, hydrogen bridges and hydrophobic interactions ${ }^{30}$, since ots inner cavity is 5 to 8 Ä diameter ${ }^{28}$, being large enough to accommodate an benzene ring, in the case of $\beta$-cyclodextrin ${ }^{31}$.

In general, complexed molecules remain oriented toward where there is maximum contact between their hydrophobic portion and the apolar cavity (Figure 4), being its hydrophilic portion in contact with cyclodextrin hydroxyl groups ${ }^{32}$.

$\beta$-cyclodextrins the most largely used cyclic dextrins for complexation with different classes of drugs, such as: anti-tumor agents (doxorubicin) ${ }^{33}$, anti-diabetes (tolbutamide) ${ }^{34}$ and anti-inflammatory (piroxicam) ${ }^{35}$, which may be administered by several routes, such as spinal, intravenous, muscular, epidural, oral, nasal and dermal ${ }^{27,33-36}$.

Natural cyclodextrins, especially $\beta$-cyclodextrin, have limited water solubility $(16.4 \mathrm{mM}$ or $18.6 \mathrm{mg} / \mathrm{ml})$ and the formation of complexes with lipophilic compounds in general results in solid complexes precipitation if solubility threshold is reached. So, numerous chemical structure changes in $\beta$-cyclodextrins have been attempted, originating more soluble derivatives, such as 2,6-dimethyl- $\beta$-cyclodextrin (DM- $\beta$-cyclodextrin), 2-hydroxypropyl- $\beta$-cyclodextrin (HP- $\beta$-cyclodextrin) and sulfated cyclodextrins, such as sulfobutylether- $\beta$-cyclodextrin (SBE- $\beta$-cyclodextrin) ${ }^{37}$.

In addition to stabilization, drugs pharmacokinetic and biopharmaceutical changes are the most significant effects of cyclodextrins complexation. These effects are especially seen in solubility and complexed drug release. As a conse- 


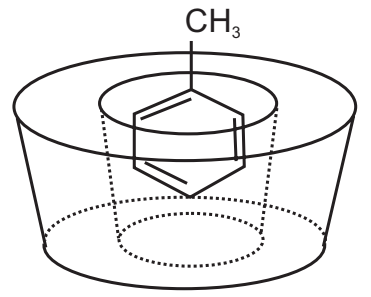

A

$(1: 1)$

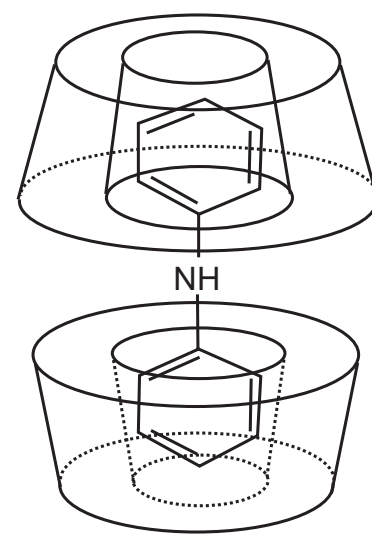

$(1: 2)$

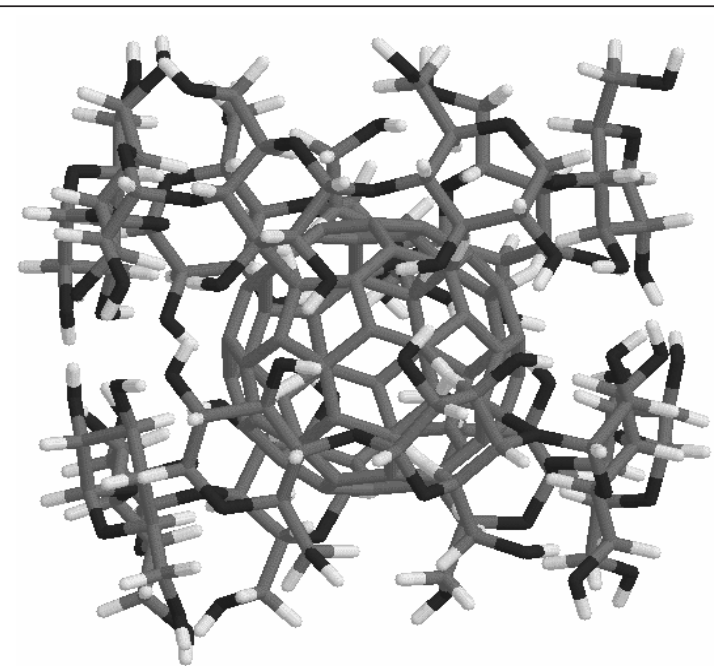

B

Figure 4 - Formation of Inclusion Complexes Between Drugs and Cyclodextrin in 1:1 and 1:2 Ratio (A) and 1:2 Complexation Representation (B)

quence, the administration of cyclodextrin-complexed drugs changes intensity and duration of their effects through low systemic drug absorption ${ }^{32}$.

This cyclodextrin property makes its use very promising for complexation with local anesthetics. In addition, studies suggest that $\beta$-cyclodextrin and some derivatives (dimethyl and hydroxypropil $\beta$-cyclodextrin) increase local anesthetics solubility - such as etidocaine, lidocaine, prilocaine, mepivacaine and, especially, bupivacaine - as well as improve complexed drugs therapeutic index ${ }^{38-42}$.

\section{CONCLUSIONS}

Therapeutic benefits of drugs traditionally administered are sometimes limited by their physico-chemical (solubility) and toxicological properties or even by physiological barriers. Through the development of drug-delivery systems it is possible to manipulate some of those properties, in addition to improve drugs therapeutic effects, thus favoring their clinical use. Studies with drug-delivery systems for local anesthetics have shown promising results.

Studies in patients have shown the applicability and efficacy of bupivacaine $(0.5 \%)$ encapsulation in liposomes for epidural administration and brachial plexus infiltration in the treatment of postoperative and chronic oncologic pain. Longer analgesia duration was observed as compared to the administration of free local anesthetics, in addition to differential nervous block potentiation. These results may be attributed to the maintenance of high drug levels in the injection site 22,23 . In spite of major advances in the development of such formulations, studies are still needed to determine the ratio of local anesthetic release from liposomes and the stabilization of preparations, as well to control some effects such as sympathetic block induction. So, changes in preparation methods and/or variations in liposomes composition have been used aiming at increasing the efficiency and encapsulation of local anesthetics ${ }^{43-46}$.

As to local anesthetics complexation with cyclodextrins, the use of $\beta$-cyclodextrin derivatives (less toxic and more soluble) with bupivacaine has shown increased anesthetic effect added to controlled systemic drug absorption after epidural administration and intramuscular infiltration in animals, promoting a formulation with potentially effective drug-delivery system for the treatment of pain ${ }^{40-42}$. These formulations, however, still need to be submitted to local neurotoxicity studies to assure their safe clinical use.

Although studies are still in progress, it is important to highlight that local anesthetics encapsulated in liposomes or complexed with cyclodextrins flag a new direction for the development of safer and more effective formulations. Surgical patients (for postoperative pain relief) or those with chronic pain (who often need repeated local anesthetic administrations for peripheral, central or autonomic nerves block) would be those benefiting the most from the development of such formulations called long duration or controlled release formulations, with longer anesthesia, lower frequency of daily administrations and decreased systemic toxicity relatively to the currently available local anesthetic drugs.

\section{REFERÊNCIAS - REFERENCES}

01. Siddall PJ, Cousins MJ - Pain mechanisms and management: an update. Clin Exp Pharmacol Physiol, 1995;22:679-688.

02. Bennett G, Deer T, Stuart DP et al - Future directions in the management of pain by intraspinal drug delivery. J Pain Symp Manag, 2000;20:44-50.

03. Åkerman B, Arweström E, Post C - Local anesthetics potentiate spinal morphine antinociception. Anesth Analg, 1988;67: 943-948. 
04. Whiteside JB, Wildsmith JAW - Developments in local anesthetics drugs. Br J Anaesth, 2001;87: 27-35.

05. de Jong RH - Local Anesthetics, $1^{\text {st }}$ Ed, USA, Mosby-Year Book, 1994;87-88.

06. Kuzma PJ, Kline MD, Calkins MD et al - Progress in the development of ultra-long-acting local anesthetics. Reg Anesth, 1997;22:543-551.

07. Ranade VV - Drug delivery systems. 1. Site-specific drug delivery using liposomes as carriers. J Clin Pharmacol, 1989;29: 685-694.

08. Lichtenberg D, Barenholz Y - Liposomes - Preparation, characterization and preservation. Method Biochem Anal, 1988;33: 337-462.

09. Grant GJ, Bansinath M - Liposomal delivery systems for local anesthetics. Reg Anesth Pain Med, 2001;26:61-63.

10. Sharata HH, Katz KH - Liposomes. Int J Dermatol, 1996;35: 761-769.

11. Malinovsky J-M, Benhamou D, Alafandy $M$ et al Neurotoxicological assessment after intracisternal injection of liposomal bupivacaine in rabbits. Anesth Analg, 1997b;85: 1331-1336.

12. Rongen HAH, Bult A, van Bennekom WP - Liposomes and immunoassays. J Immunol Meth, 1997;204:105-133.

13. Law SL, Huang KJ, Chiang $\mathrm{CH}$ - Acyclovir-containing liposomes for potential ocular delivery corneal penetration and absorption. J Control Release, 2000;63:135-140.

14. Kotwani RN, Gokhale PC, Bodhe PV et al - A comparative study of plasma concentrations of liposomal amphotericin $B$ (L-AMP-LRC-1) in adults, children and neonates. Int J Pharm, 2002;238:11-15.

15. Erridge C, Stewart J, Bennet-Guerrero et al - The biological activity of a liposomal complete core lipopolysacharide vaccine. $J$ Endotoxin Res 2002;8:39-46.

16. Stuart DD, Kao GY, Allen T - A novel long-circulating and functional liposomal formulation of antisense oligonucleotides targeted against MDR1. Cancer Gene Therapy, 2000;7:466-475.

17. Boogaerts J, Declercq A, Lafont $\mathrm{N}$ et al - Toxicity of bupivacaine encapsulated into liposomes and injected intravenously: comparision with plain solutions. Anesth Analg, 1993a;76: 553-555.

18. Boogaerts JG, Lafont ND, Luo HC et al - Plasma concentrations of bupivacaine after brachial plexus administration of liposome-associated and plain solutions to rabbits. Can J Anaesth, 1993b;40:1201-1204.

19. Yu H-Y, Sun P, Hou W-Y - Prolonged local anesthetic effect of bupivacaine liposomes in rats. Int J Pharm, 1998;176:133-136.

20. Malinovsky JM, Bernard JM, Baudriment $M$ et al - A chronic model for experimental investigation of epidural anesthesia in the rabbit. Reg Anesth, 1997a;22:80-85.

21. Malinovsky JM, Le Corre P, Meunier JF et al - A dose-response study of liposomal bupivacaine in rabbits. J Contr Rel, 1999;60: 111-119.

22. Boogaerts JG, Lafont ND, Declerq AG et al - Epidural administration of liposome-associated bupivacaine for the management of postsurgical pain:a first study. J Clin Anesth, 1994;6: 315-320.

23. Lafont ND, Legros FJ, Boogaerts JG - Use of liposome-associated bupivacaine in a cancer pain syndrome. Anaesthesia, 1996;51:578-579.

24. Simonetti MPB, Andrade MP - Anestésicos locais e opióides encapsulados em lipossomas: um avanço farmacológico em progresso. Rev. Bras. Anestesiol. 1996;46:35-42.

25. Langerman L, Grant GJ, Zakowski M et al - Prolongation of epidural anesthesia using a lipid carrier with procaine, lidocaine and tetracaine. Anesth Analg, 1992;75:900-905.
26. Mowat JJ, Mok MJ, MacLeod BA et al - Liposomal bupivacaine. Anesthesiol, 1996;85:635-643.

27. Loftsson T, Masson M - Cyclodextrins in topical drug formulations: theory and practice. Int J Pharm, 2001;225:15-30.

28. Matioli G - Ciclodextrinas e suas aplicações em alimentos, fármacos, agricultura, biotecnologia, química analítica e produtos gerais. $1^{\text {a }} \mathrm{Ed}$, Maringá, Eduem, 2000;3-5.

29. McCormack B, Gregoriadis G - Drugs-in-cyclodextrins-inliposomes: an approach to controlling the fate of water insoluble drugs in vivo. Int J Pharmac, 1998;162:59-69.

30. Bibby D, Davies NM, Tucker IG - Mechanisms by wich cyclodextrins modify drug release from polymeric drug delivery systems. Int J Pharmac, 2000;197:1-11.

31. Kalinkova GN - Studies of beneficial interactions between active medicaments and excipients in pharmaceutical formulations. Int J Pharm, 1999;187:1-15.

32. Frömming K-H, Szejtli J - Topics in Inclusion Science Cyclodextrins in Pharmacy, $1^{\text {st }}$ Ed, Hungria, Kluwer Academic Publishers, 1994;50-51.

33. Kirchmeier MJ, Ishida T, Chevrette J et al - Correlations between the rate of intracellular release of endocytosed liposomal doxorubicin and cytotoxicity as determined by a new assay. $\mathrm{J}$ Liposome Res, 2001;11:15-29.

34. Veiga F, Fernandes C, Teixeira F - Oral availability and hypoglycaemic activity of tolbutamide/cyclodextrin inclusion complexes. Int J Pharm, 2000;202:165-171.

35. Dalmora ME, Dalmora SL, Oliveira AG - Inclusion complex of piroxicam with $\beta$-cyclodextrin and incorporation in cationic microemulsion. In vitro drug release and in vivo topical anti-inflammatory effect. Int J Pharm, 2001;222:45-55.

36. Irie T, Uekama K - Pharmaceutical applications of ciclodextrins. III. Toxicological issues and safety evaluation. J Pharm Sci, 1997;86:147-162.

37. Rajewski RA, Stella VJ - Pharmaceutical applications of cyclodextrins. 2. In vivo Drug delivery. J Pharm Sci 1996;85: 1142-1169.

38. Dollo G, Le Corre P, Chevanne F - Inclusion complexation of amide-type local anesthetics with $\beta$-cyclodextrin and derivates. I. Physicochemical characterization. Int J Pharmac, 1996a; 131: 219-228.

39. Dollo G, Le Corre P, Chevanne F - Inclusion complexation of amide-type local anesthetics with $\beta$-cyclodextrin and derivates. II. Evaluation of affinity constants and in vitro transfer rate constants. Int J Pharmac, 1996b; 136: 165-174

40. Fréville JC, Dollo G, Le Corre P et al - Controlled systemic absorption and increased anesthetic effect of bupivacaine following epidural administration of bupivacaine-hydroxypropyl-betacyclodextrin complex. Pharm Res, 1996; 13:1576-1580.

41. Dollo G, Thompson DO, Le Corre P et al - Inclusion complexation of amide-type local anesthetics with $\beta$-cyclodextrin and derivates. III. Biopharmaceutics of bupivacaine-SBE7- $\beta$ ciclodextrina complex following percutaneous sciatic nerve administration in rabbits. Int J Pharmac, 1998;164:11-19.

42. Dollo G, Le Corre P, Freville JC et al - Biopharmaceutics of local anesthetic cyclodextrin complexes following loco-regional administration. Ann Pharm Fr, 2000;58:425-432.

43. Fletcher D, Le Corre P, Guilbaud $G$ et al - Antinociceptive effect of bupivacaine encapsulated in poly $(\mathrm{D}, \mathrm{L})$-lactide-co-glycolide microspheres in the acute inflammatory pain model of carrageenin-injected rats. Anesth Analg, 1997;84:90-94.

44. Garry MG, Jackson DL, Geier HE et al - Evaluation of the efficacy of a bupivacaine polymer system on nociception and inflammatory mediator release. Pain, 1999;82:49-55. 
45. Kohane DS, Lipp M, Kinney RC et al - Sciatic nerve blockade with lipid-protein-sugar particles containing bupivacaine. Pharm Res, 2000;17:1243-1249.

46. Grant GJ, Barenholz Y, Piskoun B et al - DRV liposomal bupivacaine: preparation, characterization and in vivo evaluation in mice. Pharm Res, 2001;18:336-343.

\section{RESUMEN}

Araújo DR, Pinto LMA, Braga AFA, Paula E - Formulaciones de Anestésicos Locales de Liberación Controlada: Aplicaciones Terapéuticas

JUSTIFICATIVA Y OBJETIVOS: El desenvolvimiento de sistemas de liberación controlada ha sido motivo de pesquisas desde cuatro décadas por lo menos. Desde que fue sugerida su aplicación en la industria farmacéutica, fueron obtenidos muchos resultados, especialmente en la manipulación molecular de carreadores y en el estudio de sus interacciones con las drogas encapsuladas. Esos nuevos carreadores tienen la ventaja de contornar propiedades físico-químicas limitantes (como la solubilidad acuosa o en membranas) de las drogas encapsuladas, mejorando asi la farmacodinámica (potencialización del efecto terapéutico), farmacocinética (control de la absorción y distribución de tejidos) y los efectos toxicológicos (reducción de la toxicidad local y sistémica) de las mismas. Entre los principales carreadores, se destacan los liposomas y las ciclodextrinas, que están trayendo innúmeras ventajas en el desarrollo de formulaciones para liberación controlada de anestésicos locales. Este trabajo de revisión, objetiva describir la interacción de anestésicos locales con liposomas o ciclodextrinas, el desarrollo de las pesquisas básica y clínica en esa área, además de la aplicabilidad terapéutica de esas formulaciones.

CONTENIDO: Liposomas tienen la capacidad de transportar drogas en órganos-clave, disponibilizando apenas una fracción - liberación controlada - para el sitio de acción. Ya las ciclodextrinas alteran la intensidad y la duración de efectos de las drogas a través de la baja absorción sistémica del complejo. Pesquisas básicas y clínicas, apuntan como ventajas del uso de anestésicos locales encapsulados en liposomas o complejos con ciclodextrinas la liberación lenta de la droga que prolonga la duración de la anestesia, y reduce la toxicidad para los sistemas cardiovascular y nervioso central.

CONCLUSIONES: No obstante varias pesquisas están aún en andamiento, los sistemas de liberación controlada de anestésicos locales indican una nueva dirección en el desarrollo de formulaciones anestésicas más eficaces y seguras. 